\title{
Analisis Tingkat Kepercayaan Masyarakat Terhadap Tradisi Peturunan di Desa Adat Bukti
}

\author{
I Gede Prema Utama, Made Kaisar Manik, Bayu Angga Saputra, I Made \\ Hermawan, I Komang Edy Atmaja \\ Jurusan Akuntansi, Universitas Pendidikan Ganesha
}

\begin{abstract}
Abstrak
Penelitian ini bertujuan untuk mengetahui tradisi peturunan (iuran) yang ada di Desa Adat Bukti, bagaimana tata cara implementasi dan pengelolaantradisi peturunan (iuran) yang ada di Desa Adat Bukti, beberapa besar tingkat kepercayaan masyarakat terhadap Tradisi Peturunan di Desa Adat Bukti. Dalam penelitian ini menggunakan metode kualitatif dengan menggunakan teknik pengumpulan data dengan wawancara. 1) Desa Adat Bukti masih memegang teguh tradisi peturunan yang sudah berlangsung sejak lama dengan aturuan-aturan yang telah disepakati oleh seluruh masyarakat berumat hindu di daerah Desa Adat Bukti, 2) Dasar yang melandasi sistem pemungutan dana peturunan adalah yang pertama adanya sikap atau prinsip keterbukaan dari bendesa adat Desa Pakraman, kedua adanya kesamaan tekad dan pemikiran untuk tidak melanggar peratururan yang sudah dibuat, 3) pengelolaan dana peturunan di Desa Adat Bukti sudah baik dan juga terbuka atau transparan dan adanya alur yang jelas dapat mempermudah penelusuran aliran dana jika seandainya ada penyelewangan yang terjadi.
\end{abstract}

Kata kunci: Kepercayaan, tradisi, Peturunan

\begin{abstract}
Penelitian ini bertujuan untuk mengetahui tradisi peturunan (iuran) yang ada di Desa Adat Bukti, bagaimana tata cara implementasi dan pengelolaantradisi peturunan (iuran) yang ada di Desa Adat Bukti, beberapa besar tingkat kepercayaan masyarakat terhadap Tradisi Peturunan di Desa Adat Bukti. Dalam penelitian ini menggunakan metode kualitatif dengan menggunakan teknik pengumpulan data dengan wawancara. 1) Desa Adat Bukti masih memegang teguh tradisi peturunan yang sudah berlangsung sejak lama dengan aturuan-aturan yang telah disepakati oleh seluruh masyarakat berumat hindu di daerah Desa Adat Bukti, 2) Dasar yang melandasi sistem pemungutan dana peturunan adalah yang pertama adanya sikap atau prinsip keterbukaan dari bendesa adat Desa Pakraman, kedua adanya kesamaan tekad dan pemikiran untuk tidak melanggar peratururan yang sudah dibuat, 3) pengelolaan dana peturunan di Desa Adat Bukti sudah baik dan juga terbuka atau transparan dan adanya alur yang jelas dapat mempermudah penelusuran aliran dana jika seandainya ada penyelewangan yang terjadi.
\end{abstract}

\section{Keywords : Beliefs, traditions, descent}

\section{Pendahuluan}

Desa adat di Bali adalah pemerintahan teritorial tradisional yang didalamnya terdapat warga atau krama adat sebagai perwujudan budaya bangsa yang perlu diayomi dan dilestarikan. Dalam pembagian wilayah adat, dijelaskan juga bahwa wilayahnya sudah terbagi - bagi menjadi desa adat yang juga didalamnya terdapat periangan (parahyangan) atau tempat suci seperti Tri Kahyangan sebagaimana dijelaskan dalam sumber kutipan komentar dalam Forum Diskusi Jaringan Hindu Nusantara.

Disebutkan pula bahwa desa adat di Bali menurut kutipan dari artikel Parisada Hindu Dharma Indonesia, desa adat selama ini memegang peranan yang sangat penting dalam menata dan membina kehidupan masyarakat desa adat maupun dalam proses pembangunan.

Sebagai organisasi pemerintahan, desa adat merupakan desa otonom asli, mengendalikan roda pemerintahan sendiri di dalam palemahan (wilayah)nya yang tetap hidup dan kedudukannya diakui di dalam Negara Republik Indonesia. Oleh karena itu timbul tradisi peturunan dimasyarakat. Tradisi peturunan adalah tradisi iuran yang timbul dikalangan masyarakat desa adat yang bertujuan untuk memperbaiki sarana dan prasarana 
pendukung yang ada di Desa Adat dan juga digunakan untuk pelaksanaan upacara-upacara keagamaan yang diselenggarakan di Desa Adat..

Sesuai dengan peraturan pemerintah No. 58 Tahun 2005 tentang pengelolaan keuangan daerah, mengharuskan setiap daerah mengelola keuangan secara tepat. Pengelolaan keuangan harus menjungjung tinggi prinsip akuntabilitas publik. Terlebih lagi segala hal yang terkait dengan aktivitas Desa Adat harus dipertanggungjawabkan oleh pengelola keuangan Desa Adat kepada masyarakat Desa Adat Bukti.

Berdasarkan permasalahan diatas, adapun rumusan masalah yang dilakukan yaitu Apa yang dimaksud dengan tradisi peturunan (iuran) yang ada di Desa Adat Bukti, bagaimana tata cara implementasi dan pengelolaantradisi peturunan (iuran) yang ada di Desa Adat Bukti, beberapa besar tingkat kepercayaan masyarakat terhadap TradisiPeturunan di Desa Adat Bukti.

\section{Metode}

Metode penelitian yang digunakan adalah metode wawancara. Wawancara ini saya lakukan dengan beberapa orang warga dan perangkat desa Desa Adat Bukti, Kecamatan Kubutambahan, Kabupaten Buleleng, Bali.

\section{Lokasi Penelitian}

Penelitian ini berlokasi di Desa Adat Bukti, Kecamatan Kubutambahan, Kabupaten Buleleng, Bali.

\section{Subjek Penelitian}

Subjek penelitian adalah klian desa dari Desa Bukti dan 5 orang warga yang berumat hindu dan bertempat tinggal di daerah Desa Adat Bukti.

\section{METODE ANALISA DATA}

Tehnik analisis data kualitatif dilakukan sesuai dengan pendekatan studi kasus, sehingga analisis data yang digunakan dengan cara menelaah jawaban-jawaban yang dikumpulkan yang dapat didapat dari subjek penelitian. Jawaban-jawaban tersebut diorganisir dengan cara mengidentifikasikan dan mengkategorisasikan sesuai dengan tujuan-tujuan penelitian

\section{Hasil dan Pembahasan Sejarah Desa Bukti}

Sebelum tahun 1968, Desa Bukti merupakan Desa Administrasi yang terdiri dari 2 (dua) Desa Administrasi, yaitu Desa Administrasi Bukti dan Desa Administrasi Sanih, dengan jumlah penduduk masing - masing sekitar 235 KK untuk Desa Bukti, dan sekitar $120 \mathrm{KK}$ untuk Desa Sanih.Di masing - masing Desa Administrasi, yaitu Desa Bukti dan Desa Sanih, sama - sama memiliki 1 (satu) dusun, yaitu Dusun Bukti dan Dusun Sanih di wilayah Desa Sanih.Dan juga masing - masing Desa Administrasi sama - sama memiliki 1 (satu) Desa Pakraman (Desa Adat) lengkap dengan Prahyangan (Kahyangan Tiga), yaitu Desa Pakraman (Desa Adat) Bukti berada di wilayah Dusun Bukti, Desa Administrasi Bukti. Dan Desa Pakraman (Desa Adat) Sanih berada di wilayah Dusun Sanih,Desa Administrasi Sanih.Perbedaan Wilayah Desa Administrasi antara Desa Bukti dengan Desa Sanih dengan masing - masing perbedaan adat budaya (Desa, Kala dan Patra / Desa Mawicara), membentuk karakteristik dan pola hidup budaya masyarakat yang berbeda di kedua desa.

Dengan diberlakukannya Undang - Undan Nomor : 69 Tahun 1958 tentang Pembentukan Daerah - Daerah dalam wilayah Tingkat I Bali, Nusa Tenggara Barat dan Nusa Tenggara Timar (Lembaran Negara Republik Indonesia tahun 1958 No. 122 ; Tambahan Negara Republik Indonesia No. 1655), maka Sejas Tahun 1968, Desa Bukti dan Desa Sanih dijadikan satu Desa Administrasi, yaitu Desa Bukti, yang terdiri dari Dusun Sanih dan Dusun Bukti, dengan masing-masing Desa Adat, yaitu Desa Adat Bukti di wilayah Dusun Bukti, Desa Bukti dan Desa Adat Sanih di wilayah Dusun Sanih,Desa Bukti. 
Kondisi ini nantinya diharapkan dapat membentuk kehidupan masyarakat Desa Bukti, yang saat ini terdiri dari 2 (dua) Dusun, yaitu Dusun Bukti dan Dusun Sanih agar tumbuh dan berkembang sebagai satu kesatuan masyarakat Desa Bukti yang utuh. Dengan demikian, akan dapat memberikan dampak positif terhadap setiap pembangunan di desa, serta menumbuhkan rasa tanggung jawab bersama seluruh masyarakat Desa Bukti, dengan tanpa membeda- bedakan masyarakat di wilayah Dusun Sanih dan Dusun Buktiyang sebelumnya berlatar belakang historis desa yang berbeda.

\section{Tradisi Peturunan}

Tradisi paturunan Peturunan merupakan iuran wajib krama desa yang dipungut setiap Desa Pakraman Peturunan ini dipungut dan dikenakan pada krama desa ngarep atau krama desa yang wajib dikenakan peturunan tersebut. Keterkaitan antara sabha dan peturunan ini adalah keseluruhan biaya yang berkaitan dengan pelaksanaan sabha di Desa Adat Buktidibiayai dengan dana peturunan yang dipungut dari krama desa.

Sistem pemungutan peturunan sudah ada dari sejak zaman dahulu diwariskan oleh para leluhur dan sistem tersebut masih tetap berlaku sampai sekarang ini pada Desa Pakraman di Bali, salah satunya Desa Adat Bukti sebagai salah satu kearifan lokal.

\section{Pengelolaan dan Realisasi Pemungutan Dana Peturunan}

Terkait dengan hal pelaksanaan upacara keagaaan, seperti punama tilem dan lainnya, sistem pemungutan dana peturunan dilakukan di awal sebelum upacara dilaksanakan. Ini bertujuan untuk hal pemenuhan sarana dan prasarana pada saat pelaksanaannya misalkan pembelian banten, pembelian peralatan dan perlengkapan upacara, serta biaya-biaya lainnya.

Pengelolaan keuangan pada Desa Adat Bukti terutama pada pengelolaan dana peturunan dalam pelaksanaan upacara keagamaan yang dipungut dari krama desa dilakukan dengan prinsip terbuka dan memiliki alur dan tahapan yang sesuai dengan aturan dan Awig-Awig Desa Adat Bukti sehingga dapat mempermudah penelusuran aliran dana jika seandainya ada penyelewangan yang terjadi.

Dalam pengelolaan dana peturunan ini, di Desa Adat Bukti khususnya pada akhirnya akan bermuara pada adanya suatu realisasi. Realisasi yang dimaksud disini adalah pengalokasian dana peturunan yang sudah terkumpul tersebut guna menutupi pengeluaran ataupun biaya dalam pelaksanaan upacara keagamaan. Untuk realisasi dana peturunan dalam pelaksanaan sabha di Desa Adat Bukti dapat

\section{Simpulan dan Saran KESIMPULAN}

Berdasarkan hasil wawancara terhadap para narasumber, dapat ditarik kesimpulan bahwa, 1) Desa Adat Bukti masih memegang teguh tradisi peturunan yang sudah berlangsung sejak lama dengan aturuan-aturan yang telah disepakati oleh seluruh masyarakat berumat hindu di daerah Desa Adat Bukti, 2) Dasar yang melandasi sistem pemungutan dana peturunan adalah yang pertama adanya sikap atau prinsip keterbukaan dari bendesa adat Desa Pakraman dalam penggunaan dana peturunan tersebut kemudian yang kedua adanya kesamaan tekad dan pemikiran untuk tidak melanggar peratururan yang sudah dibuat dan disepakati bersama terutama dalam hal ini adalah pembayaran peturunan untuk pelaksanaan upacara keagamaan serta adanya kesamaan krama desa untuk melaksanakan bakti dalam bentuk pelaksanaan yadnya, 3) pengelolaan dana peturunan di Desa Adat Bukti sudah baik dan juga terbuka atau transparan dan adanya alur yang jelas dapat mempermudah penelusuran aliran dana jika seandainya ada penyelewangan yang terjadi. Selain itu prinsip kejujuran juga selalu diterapkan dalam pengelolaan dana peturunan ini untuk mendapat kepercayaan dari masyarakat terhadap bendesa adat Desa Bukti.

\section{SARAN}

Adapun saran-saran yang dapat diberikan kepada Desa Adat Bukti dan Bendesa Adat Desa Bukti dan peneliti selanjutnya adalah, 1) sebaiknya untuk kedepannya sistem pemungutan dana peturunan harus terus di sosialisasikan agar semua lapisan masyarakat 
yang ada di Desa Adat Bukti mengetahui tentang adanya aturan-aturan dalam tradisi tersebut sehingga nantinya akan terus dilestarikan dan dipertahankan sebagai warisan budaya dan adat istiadat desa setempat, 2) Sebaiknya untuk prinsip keterbukaan dalam pengelolaan dan realisasi dana peturunan krama Desa Adat Bukti dalam pelaksanaan upacara keagaan dan untuk pembangunan ini harus terus dijunjung tinggi oleh bendesa adat dan seluruh masyarakat Desa Adat Bukti siapapun itu demi untuk kepercayaan dan kemajuan Desa Adat Bukti itu sendiri.

\section{Daftar Pustaka}

Anonim. 2017.

Definisi

Penelitian

Kuantitatif.

Dalam http://www.literasiinformasi.com/2017/11/definisi-penelitian-kuantitatifmenurut.html

Anonim. 2017. Siskeudes dan pembagunan desa. Dalam http://tabloiddesa.com/siskeudes-dan-pembangunan-keuangan-desa/. Diakses pada tanggal 1 juni 2018

Kemenkeu. 2018. Pagu Anggaran Kabupaten. Dalam http://www.djpk.kemenkeu.go.id/?p=5800. Diakses pada tanggal 5 juni 2018

Rayendra. 2015 Teori Metodologi Penelitian.

Dalam

Sugiyono. 2010. Metode Penelitian Kuantitatif, Kualitatif dan R\&D. Bandung: Alfabeta.

Sujarweni. 2015. Akuntansi Sektor Publik. Pustaka Baru Press. Yogyakarta: Pustaka Baru Press.

Warren, S. Carl., James M. Reeve, dan Philip E. Fess. 2008. Pengantar Akuntansi. Jakarta: Salemba Empat.

Wibisono, Nocika Lea. 2009. Penerapan PSAK No. 45 Terhadap Laporan Keuangan Organisasi Nirlaba Pusdakota Ubaya. Surabaya: Skripsi. Fakultas Ekonomi Universitas Surabaya.

Winarni, F ., dan G., Sugiyarso. 2001. Konsep Dasar dan Siklus Akuntansi. Yogyakarta: Penerbit Media Presindo 